Egypt. Acad. J. Biolog. Sci., 13(3):283-298 (2020)

Egyptian Academic Journal of Biological Sciences

A. Entomology

ISSN 1687- 8809

http://eajbsa.journals.ekb.eg/

\title{
Studying the Interaction Between Asphondylia punica and Its Host Plant, Atriplex halimus, and Predicting Their Potential Geographic Distribution in Egypt by Using Maxent Technique
}

Sanad H. Ragab ${ }^{1}$, Mohamed Kamel ${ }^{2}$, Ahmed S. Bream ${ }^{1}$ and Mohamed M. Moursy ${ }^{3}$.

1- Department of Zoology, Faculty of Science, Al-Azhar University, Nasr City, Cairo, Egypt.

2- Department of Environmental Basic Sciences, Institute of Environmental Studies and Research, Ain shams University, Egypt.

3- Department of Botany and Microbiology, Faculty of Science, Al-Azhar University, Nasr City, Cairo, Egypt.

Email: sanadragab@azhar.edu.eg

\section{ARTICLE INFO}

Article History

Received:15/7/2020

Accepted:29/9/2020

Keywords:

Galls,

Distribution,

Maxent,

Mediterranean

coast,

Interactions, Asphondylia punica, Atriplex halimus.

\section{ABSTRACT}

Galls and their inducing insects represent one of the most challenges that facing entomologists because of their unique life history and the highly characteristic gall structure. Gall-inducing insects and their distributions in Egypt of little studies which depend on few researchers from countries of Europe during their scientific journeys. Asphondylia punica (Diptera: Cecidomyiidae) is associated with one of the most important medicinal plants, the Atriplex halimus (Chenopodiaceae). A. punica induces fusiform swellings galls on the stem of $A$. halimus with multiple chambers. The interaction between the gall inducer Asphondylia punica and its host plant A. halimus were studied. The results indicated that there was a significant correlation between the number of galls per plant and the plant cover but there was no correlation between the number of galls per plant and altitude. The predicted distributions of Asphondylia punica in Egypt were done by using MaxEnt technique. The results showed that the prediction distribution of Asphondylia punica and its host plant Atriplex halimus is concentrated in Mediterranean coastal regions.

\section{INTRODUCTION}

Gall inducers are about 13,000 known species in the world, approximately $2 \%$ of total insect species (Dreger-Jauffret \& Shorthouse, 1992; Raman et al., 2005). The prominent species in the order Coleoptera, Diptera, Hemiptera, Hymenoptera, Lepidoptera, and Thysanoptera are amongst the gall-inducing insects (Shorthouse and Rohfritsch, 1992, Maia, 2006, Price, 2005). Among these, Diptera and Hymenoptera are the largest numbers of gallinducing species (Espirito-Santo and Fernandes, 2007). Gall-inducing insects are capable of changing the growth pattern of a host plant, alter the vegetative tissue structure, and lead the host to develop a nutrient-rich, non-small food supply, along with an environmentally insulated protective structure (Price et al., 1986 \&1987).

Galls are normal plant structures, which grow modified, invariably symmetrical, due to the messages of the inducing insects (Mani 1964, Raman 2011). The larval stages of gall inducer live in them and provide nourishment and protection for a certain period of time. The 
biology and ecology of the inductive insect have a strong impact on the morphology and physiology of the plant (Shorthouse and Rohfritsch 1992, Raman, et al., 2005).

Gall-inducing insects have several ecological services including pollination (Kjellberg et al., 2005 and Borges 2015). Some of gall midge species are economically important, it can cause damage to agricultural plants (Darvas et al., 2000) and to forest trees (Skuhravá \& Roques 2000; Drooz 1985). Some galls have medicinal values, they contain tanins that are used for tanning in (Gerling, et al., 1976). Also, Galls are used commercially as dye hair and other tissues in addition to written ink in the 17th century (Fernandes and Martins 1985). Gall save the gall-inducing insect larvae against climatic changes and natural enemies and provide it with nutation (Raman et al., 2005; Bailey et al., 2009).

A. halimus used as forage for sheep, goats, cattle, and camels (Khattab, 2007). It is used for the treatment of syphilis (Rolleston, 1942). The leaves are used to treat heart diseases and diabetes and rheumatism (Said et al., 2002). The ash is used as an alkali to make soap (Uphof, 1968). Extracts material of A. halimus is used as antibacterial activity against various Grampositive and negative pathogenic bacteria (Abdel Rahman et al., 2011). Endophytic fungi isolated from A. halimus showed antibiotic activity (Peláez et al., 1998).

Large galls on the stems of Atriplex halimus L. (Chenopodiaceae) formed by larvae of Asphondylia punica. Small galls on Atriplax halimus were discovered in Dorchin et al., (2014) redescribed the gall inducer, and gave $A$. conglomerata a junior synonym as instead of $A$. punica. It is also collected from Alexandria, El-Amria district (Elsayed et al., 2015). It is found in some countries such as Italy (Sicily) (Skuhravá et al., 2007), Canary Islands (Graham \& Gijswijt 1998), Greece (Crete) (Skuhravá, 1996; Skuhravá \& Skuhravý 1997), and Libya, Tunisia Israel, and Egypt (Debski, 1918).

Species dispersion models depend on the connection between species distribution and the ecological factors variables determining suitable habitats and limiting barriers. Likewise, these methodologies can be helpful to predict suitable habitats for species in regions where their distribution completely unknown (Guisan and Thuiller, 2005). Species distribution models are generally useful in several ecological, biological, and biogeographical applications to predict species distributions in the past, now and in the future (Guisan and Thuiller, 2005). Model investigations are very important in biological studies; Its predictive abilities shed light on many issues, such as raising protected species distribution or possible expansion of invasive species (Beck, 2013; Fourcade et al., 2014). MaxEnt technique is popular due to its easy to use (Philips and Elith, 2013). The MaxEnt technique can be used to predict the potential distribution of a target species when it satisfies the maximum entropy under different conditions, it can achieve highly accurate results with available appearance data only. Specifically, MaxEnt analyzes the location data to predict the potential distribution of the target species, dependent on environmental variables. (Phillips et al., 2006).

Over the world, several studies were done by using MaxEnt, It has been used to predict the potential distribution of Phenacoccus solenopsis in India (Kumar et al., 2014). Also, in Europe, distributions of large pine weevil and horse-chestnut leaf miner were predicted (Barredo et al., 2015). However, in South Korea, apart from one study that predicted the potential distribution of the Pochazia shantungensis, a planthopper (Kim et al., 2015).

In Egypt, some studies were performed using species distribution models for predicting the potential geographic distribution of several species (El Alqamy et al., 2010, Kamel et al., 2012).

The aim of this work was to study the interactions between the gall-inducing insects Asphondylia punica and their host plants A. halimus and to predict their potential geographic distribution in Egypt by using maxent technique. 


\section{MATERIALS AND METHODS}

\section{Study Area:}

The current study was conducted in some regions of the Mediterranean coastal land. The chosen sampling sites for A. halimus were Merghem, El-tafaroa, Al hawaria, Burg El-arab, El-gharbaniat, El- amria, and Abd-elkader (Fig. 1). The study sites were visited periodically in the period from Feb. 2019 to Jun. 2020, once every two months. Egypt is a large country and its territory occupies $1,010,000 \mathrm{~km}^{2}$ and represents the westernmost part of the Middle East or Near East. Egypt's north coast extends from Sallum for approximately $970 \mathrm{~km}$ east to Rafah, with an approximate width of 15-20 km in a north-south direction (El-Hadidi, 1981). Egypt has its Mediterranean coastline divided into four areas: Eastern Coast (from El-Arish to Port Said), North (Bardawil, Southern, Manzala and Burullus) and Deltaic (Mariout), Central (Alexandria) and Western (from Al-Agami to Salloum); and Southwest (Mariout), Edka, North (Southern); and Southwest (Eastern) (El-Hadidi, 1981). 2,426 plant species were recorded in Egypt (Täckholm 1974). The Mediterranean coast region has about 1083 plant species and an annual rainfall of 20-100 mm was received (El Hadidi and Hosni, 1996). Only about 255 species recorded from this territory, 18 known species are endemic (El Hadidi and Hosni, 1996). Regions of the Mediterranean coast are moderate to warm temperatures and little precipitations recorded in the winter months (Osman and El-Garf, 2015).

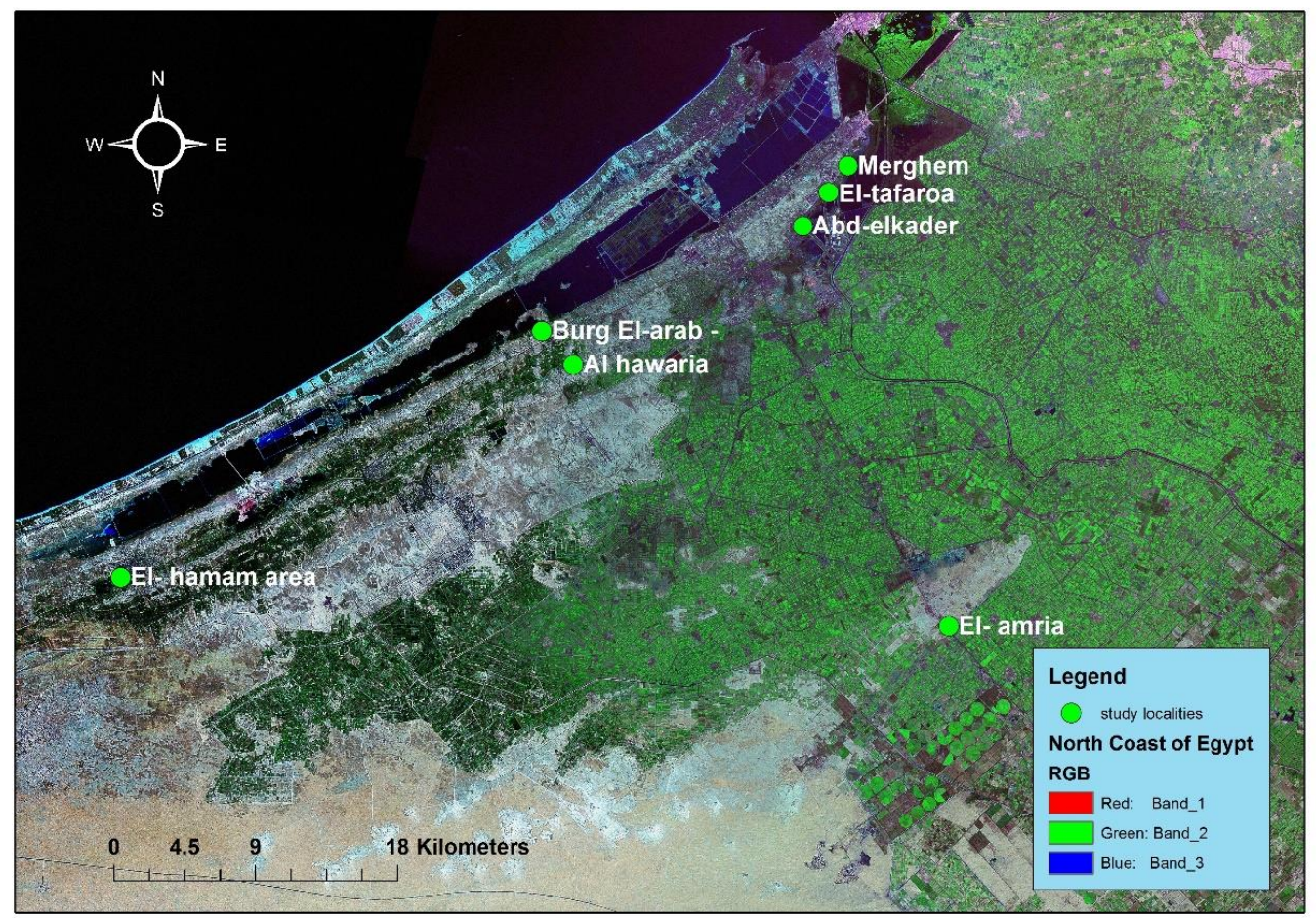

Fig. 1. Location map showing the sampling sites in some regions of Egypt, especially the Mediterranean coast. (Map source: IESR, GIS unit \& google map https://www.google.com.eg/maps/@30.9620935,29.5970038,11z).

\section{Study Plants:}

Atriplex halimus (Chenopodiaceae) is a straight, perennial, shrub, reached to $3 \mathrm{~m}$ in height and bark being silvery-white in colour. It has numerous kidney-shaped fruits, 3.5-4 x 5$6 \mathrm{~mm}$. It has brown to dark brown $1.5 \mathrm{~mm}$ seeds (Flora of Pakistan, 2018). It has 10-30 mm long and 5-20 mm wide alternate leaves and has yellowish or green flowers (Tutin et al., 1993). It lost some leaves during the warm dry summers (Walker, 2014). The recorded locations of $A$. halimus in Egypt is shown in (Table 1). 
Table 1: The recorded locations of A. halimus in Egypt

\begin{tabular}{|c|c|c|c|c|}
\hline \multirow{2}{*}{ No. } & \multirow{2}{*}{ Location } & \multicolumn{2}{|c|}{ Coordinates } & \multirow{2}{*}{ References } \\
\hline & & latitude & longitude & \\
\hline 1 & Nobaria & 30.147114 & 30.60701 & Hegazi, E. M et al, (1980) \\
\hline 2 & $\begin{array}{l}\text { Abo-Kir area ( } 22 \mathrm{~km} \text { east of } \\
\text { Alexandria) }\end{array}$ & 31.3164 & 30.0617 & Hegazi, E. M et al, (1980) \\
\hline 3 & Fayoum & 29.3039 & 30.8453 & Al-Sherif, E. A.et al., (2018) \\
\hline 4 & Mariut Lake & 31.147 & 29.3039 & Zahran, M. A., \& Willis, A. J. (2008) \\
\hline 5 & Helwan Desert & 29.9036 & 31.4050 & Zahran, M. A., \& Willis, A. J. (2008) \\
\hline 6 & Gebel Ugma sinai & 29.3741 & 33.6807 & Zahran, M. A., \& Willis, A. J. (2008) \\
\hline 7 & Wadi El-Natrun & 30.7367 & 30.3477 & Abd El-Ghani, M. M., et al., (2015) \\
\hline 8 & Burullus & 31.417 & 30.8283 & Shaltout, K. H, \& Al-Sodany, Y.M (2008) \\
\hline 9 & Sallum & 31.56667 & 25.15 & Amer, W. M. \& Amany. S. A. (2014) \\
\hline 10 & Rosetta & 31.4 & 30.41667 & Amer, W. M. \& Amany, S. A. (2014) \\
\hline 11 & El-Mahmoudia & 31.13333 & 30.2 & Amer, W. M. \& Amany, S. A. (2014) \\
\hline 12 & $221.5 \mathrm{~km}$ Alex-Matruh & 31.06667 & 29.56667 & Amer, W. M. \& Amany, S. A. (2014) \\
\hline 13 & $227 \mathrm{~km}$, Alex-Matruh & 31.08333 & 29.63333 & Amer, W. M. \& Amany, S. A. (2014) \\
\hline 14 & $237 \mathrm{~km}$, Alex-Matruh & 31.11667 & 29.75 & Amer, W. M. \& Amany, S. A. (2014) \\
\hline 15 & Abu Qir & 31.31667 & 30.06667 & Amer, W. M. \& Amany, S. A. (2014) \\
\hline 16 & Gamasa & 31.43333 & 31.53333 & Amer, W. M. \& Amany, S. A. (2014) \\
\hline 17 & $140 \mathrm{~km}$, Alex-Matruh & 30.83333 & 28.2 & Amer, W. M. \& Amany, S. A. (2014) \\
\hline 18 & $10 \mathrm{~km}$ from El-Alamein & 30.81667 & 28.98333 & Amer, W. M. \& Amany, S. A. (2014) \\
\hline 19 & El-Busseili & 31.33333 & 30.41667 & Amer, W. M. \& Amany, S. A. (2014) \\
\hline 20 & Maadi desert & 29.96667 & 31.25 & Amer, W. M. \& Amany, S. A. (2014) \\
\hline 21 & Wadi Digla & 29.95 & 31.33333 & Amer, W. M. \& Amany, S. A. (2014) \\
\hline 22 & Wadi Digla & 29.93333 & 31.48333 & Amer, W. M. \& Amany, S. A. (2014) \\
\hline 23 & Wadi Hof sitel & 29.86667 & 31.41667 & Amer, W. M. \& Amany, S. A. (2014) \\
\hline 24 & Wadi Haggag, Sinai & 28.86667 & 34.41667 & Amer, W. M. \& Amany, S. A. (2014) \\
\hline 25 & Ain Solkhna S. of Suez & 29.61667 & 32.31667 & Amer, W. M., \& Amany, S. A. (2014) \\
\hline 26 & Ain Sokhna S. of Suez site 2 & 29.61667 & 32.31667 & Amer, W. M., \& Amany, S. A. (2014) \\
\hline 27 & $206 \mathrm{~km}$ Alex-Matruh & 30.88333 & 29.4 & Amer, W. M. \& Amany, S. A. (2014) \\
\hline 28 & $26 \mathrm{~km}$ east of Matruh & 31.23333 & 27.53333 & Amer, W. M., \& Amany, S. A. (2014) \\
\hline 29 & Abu Matamir & 30.9 & 30.16667 & Amer, W. M. \& Amany, S. A. (2014) \\
\hline 30 & Sidi Krer & 31.16667 & 29.63333 & Amer, W. M. \& Amany, S. A. (2014) \\
\hline 31 & $11 \mathrm{~km}$ east of Sallum & 31.53333 & 25.33333 & Amer, W. M. \& Amany, S. A. (2014) \\
\hline 32 & Idko & 31.3 & 30.3 & Amer, W. M. \& Amany, S. A. (2014) \\
\hline 33 & Ras El Helama & 31.25 & 27.86667 & Amer. W. M. \& Amany. S. A. (2014) \\
\hline 34 & Gamasa & 31.56667 & 31.53333 & Amer, W. M. \& Amany, S. A. (2014) \\
\hline 35 & Sinai & 31.4 & 342 & Amer W M \& Amany S A (2014) \\
\hline 36 & Omayed area & 30.822 & 29.196 & Salem, B. (2014) \\
\hline
\end{tabular}

\section{Samples Collection and Identification:}

Field collections of galls were done from some regions of the Mediterranean coast. Some of the immature stages of the insect inside the galls were collected from the field and reared in the laboratory at the Faculty of Science, Al Azhar University to get emerged adults for identification. In $70 \%$ ethanol for morphological analysis Larvae, pupas, and adults from gall midges have been preserved. Width, length, and height of each plant within the sample were measured using a tape meter, in addition, the number of galls on different parts of the plant was counted. Plant samples were identified according to (Boulos, 1999).

\section{Data Analysis:}

All data were analyzed by using SPSS computer package (PASW Statistics Ver.20). Correlation between altitude, plant size, and the number of galls per plant was performed by using Pearson correlation test. Also, the mean number of galls per plant was compared between different localities by using a one-way ANOVA test.

\section{Mapping and Predicting Distributions of Plant Species:}

Distributional data for the presence of Atriplex halimus reported by using GPS (Garmin XL 12). Visiting for the study localities occurred regularly during the life cycle of the plant gall formation, providing information on the presence/absence of the species. The prediction of the potential geographic distribution of gall-inducing insects was built by using MaxEnt 
technique with environmental variable layers for the study area, such as altitude, temperature, moisture, etc (Phillips et al., 2004, 2006).

\section{Environmental Data of The Model:}

The model used many data sets as raster grids. Environmental predictors were classified into climatic data and topographical variables. The WorldClim data set (Hijmans et al., 2005; http:/www.worldclim.org/bioclim.htm) provided 19 bioclimatic variables (Table 1) that were more biologically meaningous in determining an eco-physiological tolerance of a species (Graham et al., 2006). The topographical data consists of a series of data include altitude. The collection of partial data $(\sim 1 \mathrm{Km})$ from the Shuttle Radar Topography Mission (SRTM) was used with the Altitude raster. Additionally, we acquired review distributional information for A. halimus from the Mediterranean basin database and distributed writing next to our solid observational information.

Table 1: The WorldClim climatic variable names

\begin{tabular}{|l|l|}
\hline & Variable Definition \\
\hline Bio1 & Annual Mean Temperature. \\
\hline Bio2 & Mean Diurnal Range (Mean of monthly (max temp - min temp). \\
\hline Bio3 & Isothermality (P2/P7) $(* 100)$. \\
\hline Bio4 & Temperature Seasonality (standard deviation *100). \\
\hline Bio5 & Max Temperature of Warmest Month. \\
\hline Bio6 & Min Temperature of Coldest Month. \\
\hline Bio7 & Temperature Annual Range (P5-P6). \\
\hline Bio8 & Mean Temperature of Wettest Quarter. \\
\hline Bio9 & Mean Temperature of Driest Quarter. \\
\hline Bio10 & Mean Temperature of Warmest Quarter. \\
\hline Bio11 & Mean Temperature of Coldest Quarter. \\
\hline Bio12 & Annual Precipitation. \\
\hline Bio13 & Precipitation of Wettest Month. \\
\hline Bio14 & Precipitation of Driest Month. \\
\hline Bio15 & Precipitation Seasonality (Coefficient of Variation). \\
\hline Bio16 & Precipitation of Wettest Quarter. \\
\hline Bio17 & Precipitation of Driest Quarter. \\
\hline Bio18 & Precipitation of Warmest Quarter. \\
\hline Bio19 & Precipitation of Coldest Quarter. \\
\hline
\end{tabular}

\section{Statistical Validation of The Model:}

A random records partition into 75 percent of the points were used for model building, species prediction "training data" and 25 percent for model testing "testing data" (extrinsic and independent test data sets were used for the evaluation of the model's predictive performance). The calculation of the area under the curve (AUC) was performed for statistical validation of the model. AUC is used as an indicator of the model's accuracy (Phillips, 2016). The AUC is between 0 and 1. An AUC of 0.5 suggests a normal, and an AUC of 1 reveals a perfect model (Phillips et al., 2004, Phillips et al., 2006). The present study used The AUC classification system suggested by (Hosmer et al., 2000). The AUC values are listed as: $0.5-0.6=$ No discrimination; $0.6-0.7=$ bad discrimination; $0.7-0.8=$ acceptable discrimination; $0.8-0.9$ $=$ excellent discrimination; $0.9-1.0=$ outstanding discrimination (Hosmer et al., 2000). The internal jackknife test of the MaxEnt model was used to calculate the variables that most contribute to the development of the model. Additionally, Maxent provided the percentage contribution of each variable to the final model, according to the value of the increase in the model gain provided by each variable (Phillips et al., 2006). 


\section{RESULTS}

Insects that Induced Galls:

Asphondylia punica Marchal, 1897 (Diptera: Cecidomyiidae) larvae induce large galls on several parts of Atriplex halimus L. (Chenopodiaceae). The galls (fig. 2) grew on the stems, and, apical and axillary buds of A. halimus. Fusiform galls bear a number of protuberances, each containing a gall chamber. They are consist of several densely stunted leaves. The stem inside is stunted and swollen to a very hard. The fresh galls are green but become yellowish after the gall midges emergence and may still be attached to the plant until the next season. Two generations were recorded during a year. One was recorded from November to April and anther was recorded from May until October.

Factors Affecting the Distribution of The Insect Galls Induced on A. halimus:

\section{Correlation Between the Number of Galls Per Plant, Plant Cover, And Altitude:}

There was a significantly positive correlation between the number of galls per plant and the plant cover within the study locations $(\mathrm{r}=0.296, \mathrm{P}<0.05)$. Meanwhile, there was no significant correlation between the number of galls per plant and the altitude within the study localities (Fig. 3).

\section{Spatial Distribution of The Number of Galls Induced on A. halimus Among Different Localities:}

The number of galls induced on A. Halimus showed a significant difference among various localities (Merghem, El-Tafaroa, Al Hawaria, Burg El-arab, El-Gharbaniat, El- Amria and Abd-Elkader) $(\mathrm{F}(6,50)=1.187 \mathrm{P}<0.05)$ (Fig. 4). El-Gharbaniat showed the greatest mean number of galls per plant 37.50; as compared to 32.50, 30.71, 29.50, 19.54, 15.00 and 4.37 at Al Hawaria, Merghem, El- Amria, El-Tafaroa, Burg El-Arab and El- Abd-Elkader, respectively.

\section{Spatial Prediction Model of A. halimus:}

\section{The Predicted Distribution Range of A. halimus in Egypt:}

The model of MaxEnt for A. halimus is shown in (Fig. 5). The predicted distribution habitat of $A$. halimus covers broad Mediterranean coastal areas, in addition to some areas in the Nile land region, the Red Sea coast, and South Sinai. Eighteen presence records used for training the model and five for testing. The AUC (Fig. 6) for the training points was 0.947and for test points was 0.865 , with a standard deviation of 0.033 ; The AUC exceeded 0.90, indicating outstanding discrimination for A. halimus. The minimum training presence among training points was 9.819. At this threshold, the fractional predicted area was 0.218 and the omission rate for test points was 0.000 . The model classifies the test points correctly significantly more than a random model $(\mathrm{p}<0.001)$.

\section{Effect of Predictor Variables in The Representation of The Maxent Model for $A$.} halimus:

According to the results of the variables contribution heuristic test (Fig. 7). A. halimus showed high sensitivity to Precipitation of Coldest Quarter (BIO19), Temperature Annual Range (P5-P6) (BIO7), Precipitation of Wettest Quarter (BIO16), Mean Diurnal Range (Mean of monthly (max temp - min temp) (BIO2), Precipitation of Wettest Month (BIO13), Precipitation of Warmest Quarter (BIO18), and Precipitation Seasonality (Coefficient of Variation) (BIO15), with contribution percentage equal to $24 \%, 21 \%, 17 \%, 16 \%, 9 \%, 8 \%$, and $5 \%$, respectively.

The MaxEnt model's internal jackknife test of variable importance showed that Max Temperature of Warmest Month (BIO5) and Precipitation of Warmest Quarter (BIO18) were the most important predictors of $A$. halimus habitat distribution. These variables presented higher gains that included the most information as compared to the other variables. 


\section{Spatial Prediction Model of $A$. punica:}

\section{The Predicted Distribution Range of $A$. punica in Egypt:}

The model of MaxEnt for A. punica is shown in (Fig. 8). The predicted distribution habitat of A. punica is mainly concentrated in some areas of the Nile delta north coast. Six presence records used for training, and two for testing. The AUC (Fig. 9) for the training points was 1.000 and for the test, points were 0.997 , with a standard deviation of 0.001 ; The AUC was greater than 0.90 , indicating outstanding discrimination for A. punica. The minimum training presence among training points was 48.778. At this threshold, the fractional predicted area was 0.001 and the omission rate for test points was 0.000 . The model classifies the test points correctly significantly more than a random model $(\mathrm{p}<0.001)$.

2. Effect of Predictor Variables In The Representation of the MaxEnt Model for A. punic.

According to the results of the variables contribution heuristic test (Fig. 10). A. punica showed high sensitivity to Precipitation of Wettest Quarter (BIO16), Temperature Seasonality (BIO4), Precipitation of Warmest Quarter (BIO18), Precipitation of Wettest Month (BIO13), Precipitation Seasonality (Coefficient of Variation) (BIO15), Min Temperature of Coldest Month (BIO18) and altitude, with contribution percentage equal to 41\%, 30\%, 12\%, 8\%, 4\%, $3 \%$, and $2 \%$, respectively.

The internal jackknife test for MaxEnt showed that Wettest Quarter Precipitation (BIO16) is the most important predictor of A. punica habitat distribution. This predictor presented higher gains that included the most information as compared to the other variables.
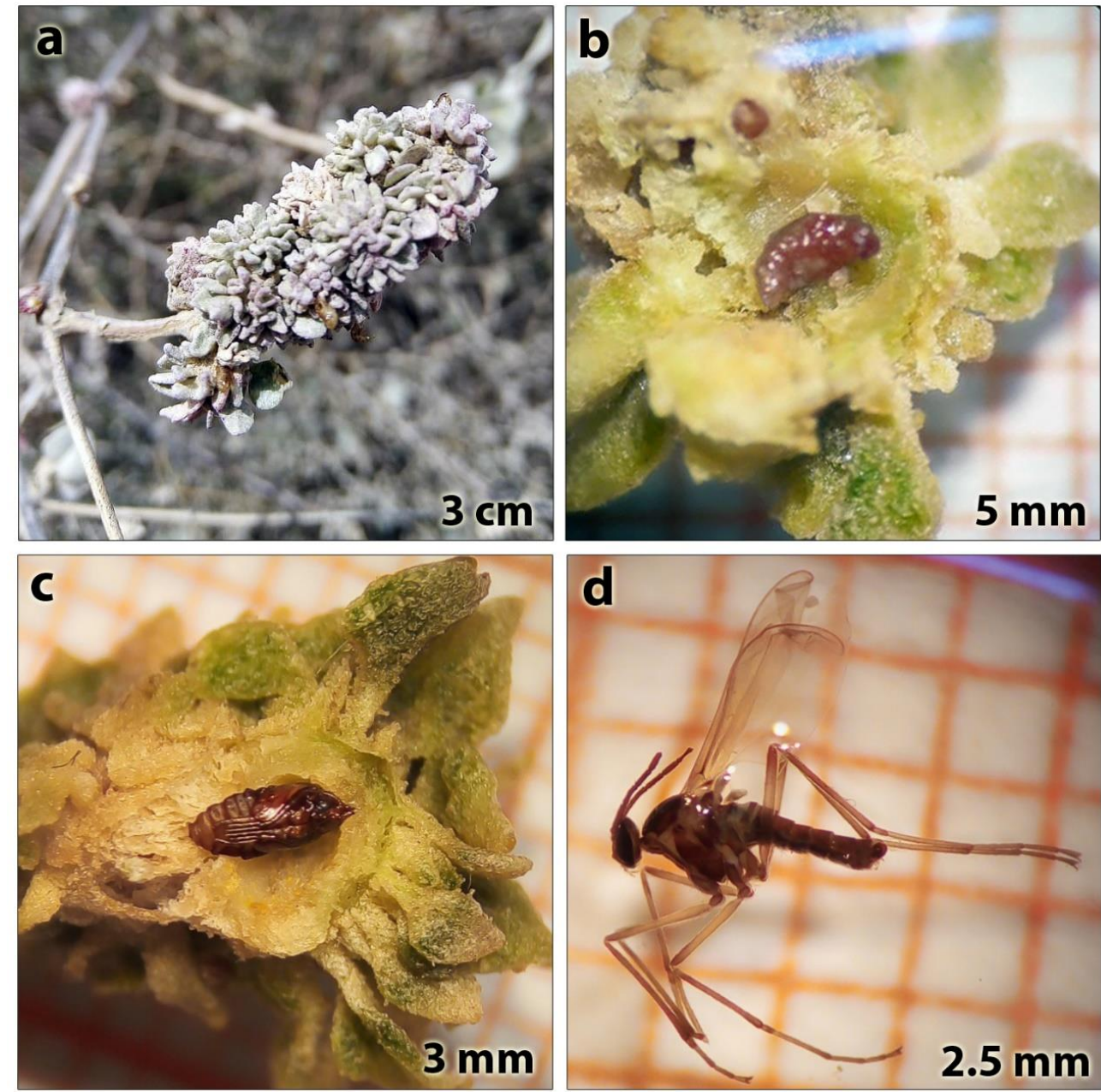

Fig. 2. The gall-midge Asphondylia punica (Diptera: Cecidomyiidae); (a) Asphondylia punica gall, (b) larvae (5 mm), (c) pupa (3 $\mathrm{mm})$, and (d) adult $(2.5 \mathrm{~mm})$. 


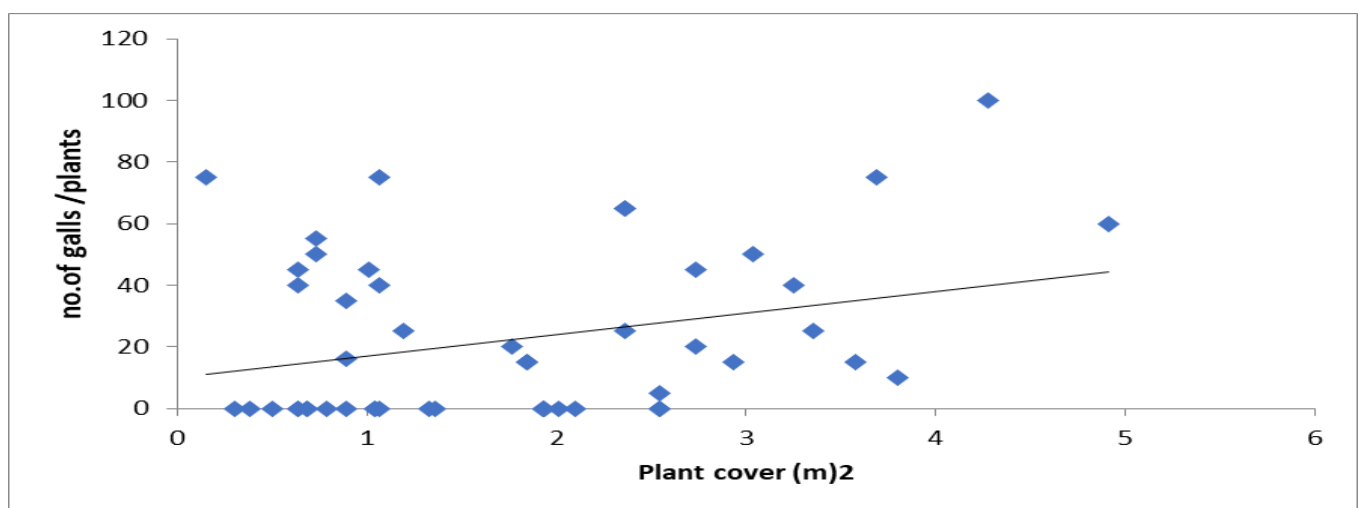

Fig.3. The relationship between the number of galls per plant and the plant cover within the study localities.

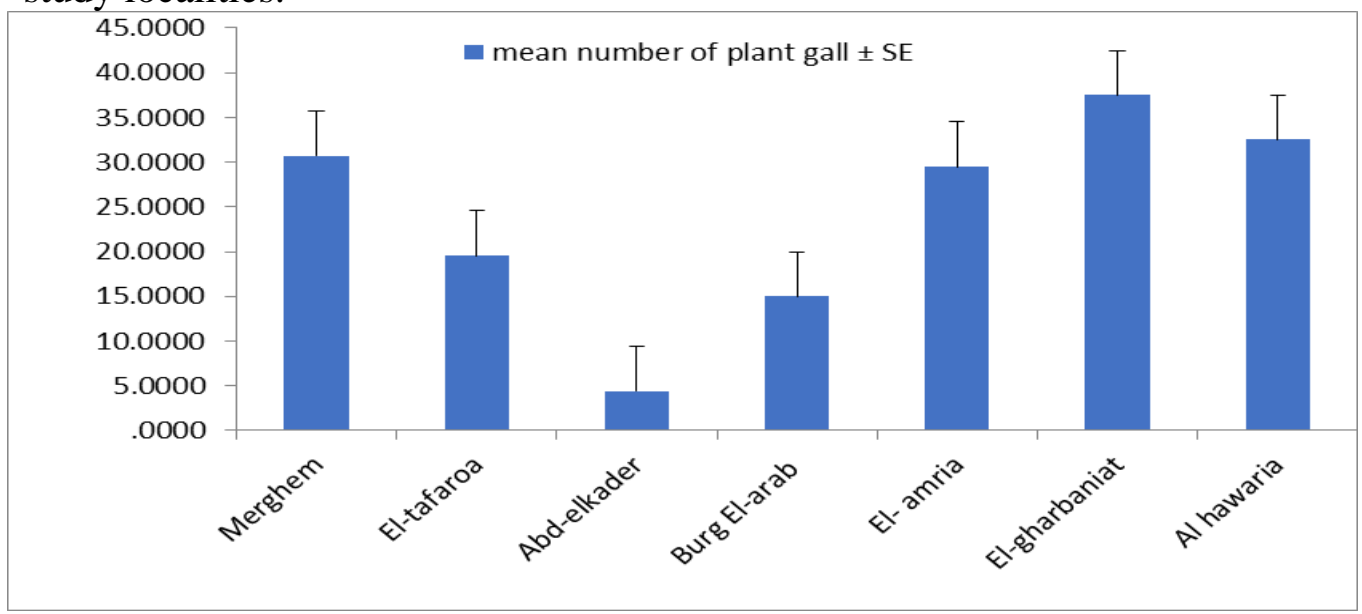

Fig. 4. The spatial pattern of gall distribution on the A. halimus among different study localities

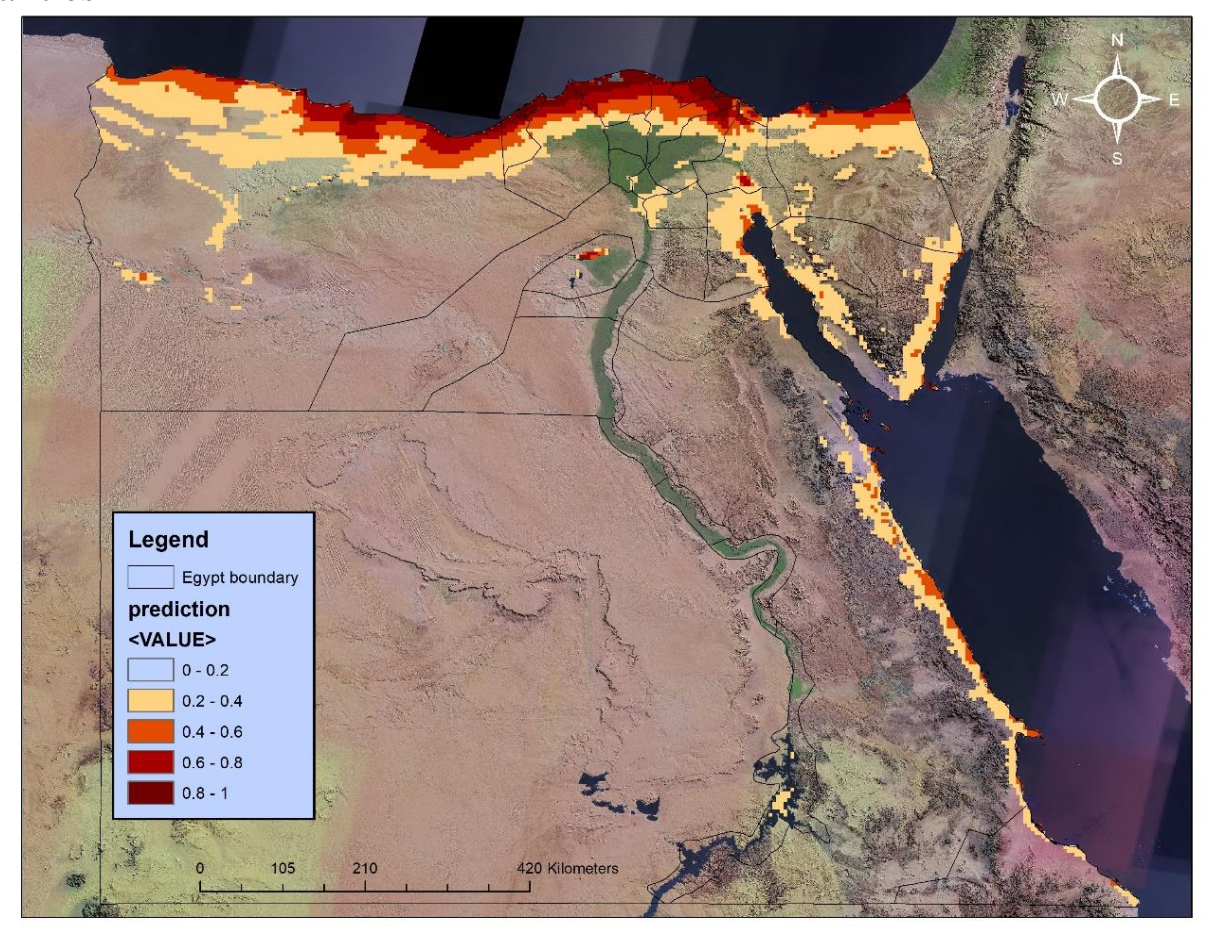

Fig. 5. The predicted distribution range of the A. halimus according to the MaxEnt model. (Map source: IESR, GIS unit \& google map https://www.google.com.eg/maps/ @27.4846068,31.3939550,6z). 


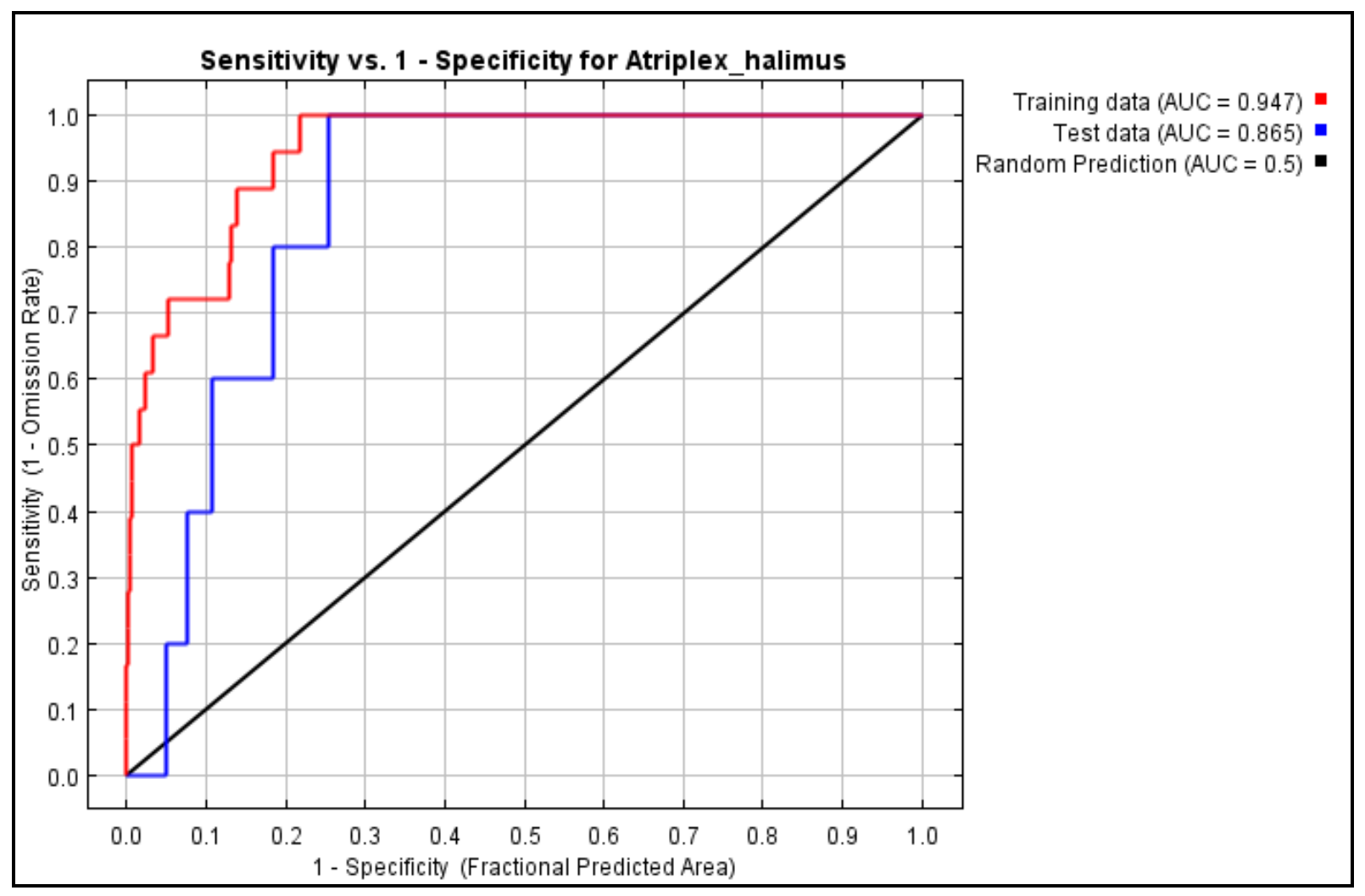

Fig.6. Training data $(\mathrm{AUC}=0.947)$ and test data $(\mathrm{AUC}=0.865)$ compared to random prediction $(A U C=0.5)$ in the receiver operating characteristic $(\mathrm{ROC})$ curve for the representation of the MaxEnt model for A. halimus.

\section{Analysis of variables contributes}

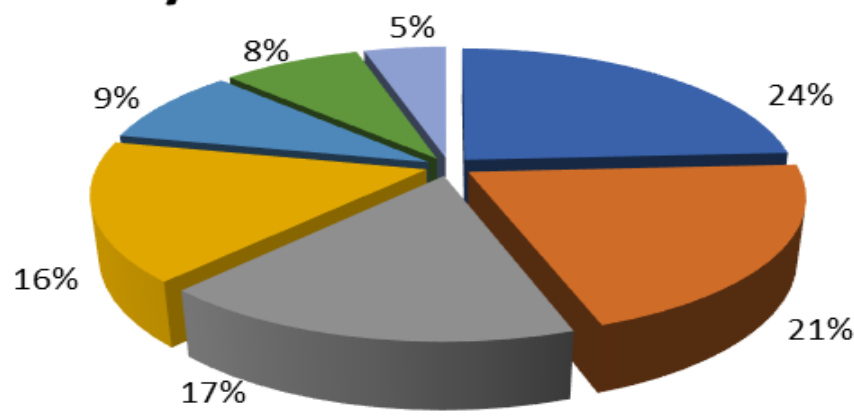

- bio19:Precipitation of Coldest Quarter

bio7: Temperature Annual Range (P5-P6)

- bio16:Precipitation of Wettest Quarter

bio2:Mean Diurnal Range (Mean of monthly (max temp - min temp)

- bio13:Precipitation of Wettest Month

bio18: Precipitation of Warmest Quarter

bio15:Precipitation Seasonality (Coefficient of Variation)

Fig.7. Analysis of variables contributes to the prediction distribution model of A. halimus 


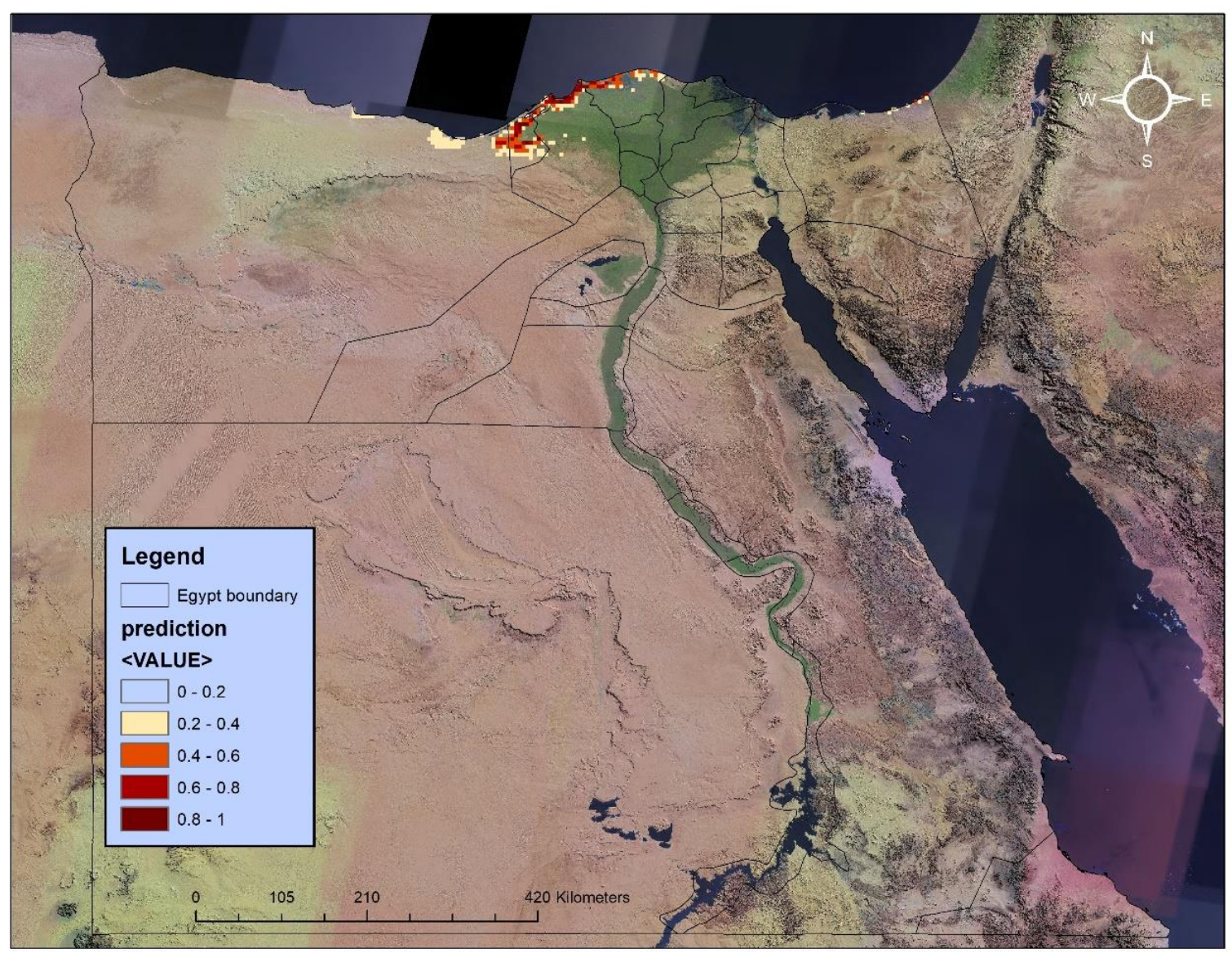

Fig. 8. The predicted distribution range of the A. punica according to the MaxEnt model. (Map source: IESR, GIS unit \& google map https://www.google.com.eg/maps /@27.4846068,31.3939550,6z).

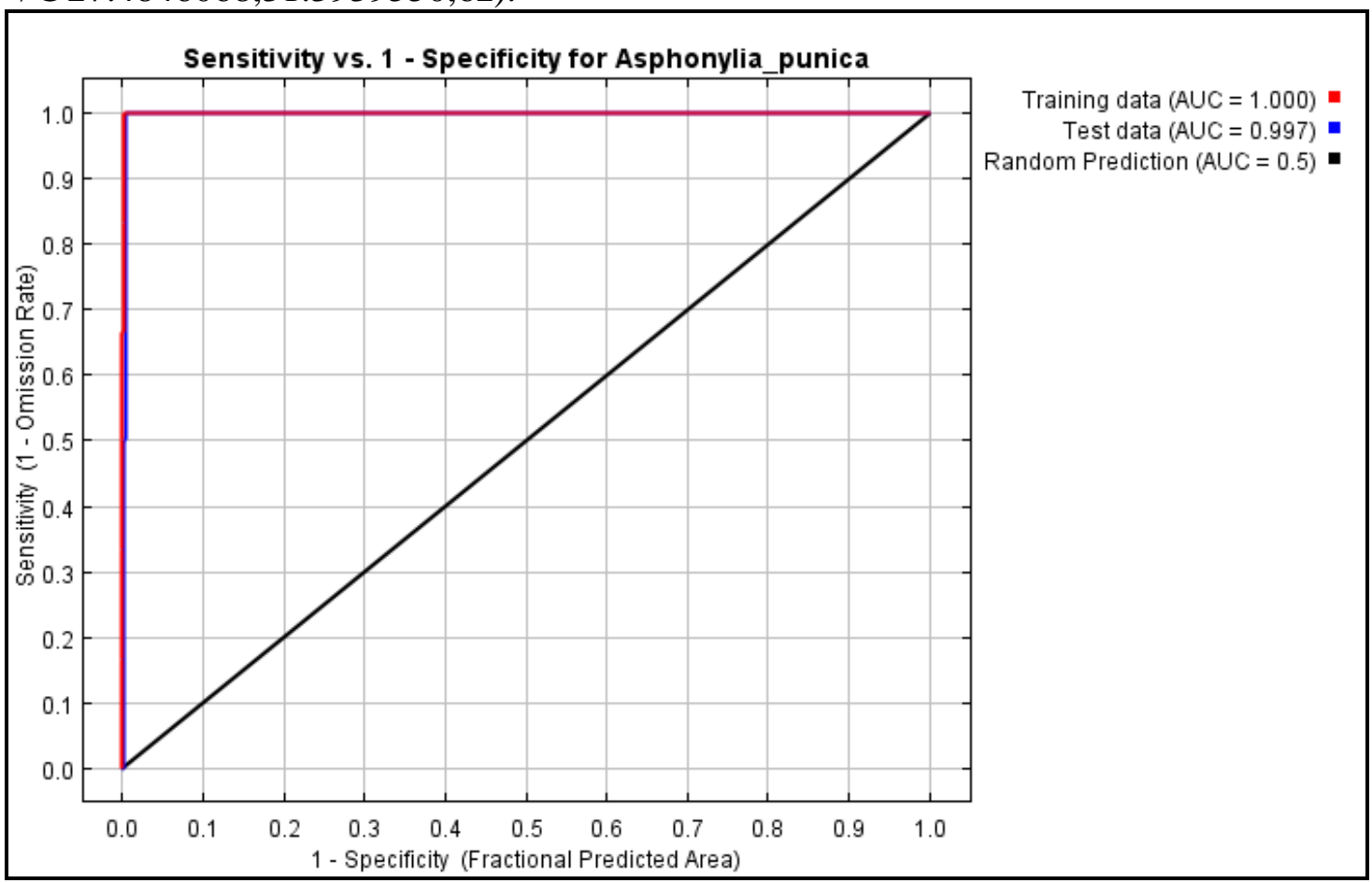

Fig.9. Training data $(\mathrm{AUC}=1.000)$ and test data $(\mathrm{AUC}=0.997)$ compared to random prediction $(\mathrm{AUC}=0.5)$ in the receiver operating characteristic $(\mathrm{ROC})$ curve for the representation of the MaxEnt model for A. punica. 


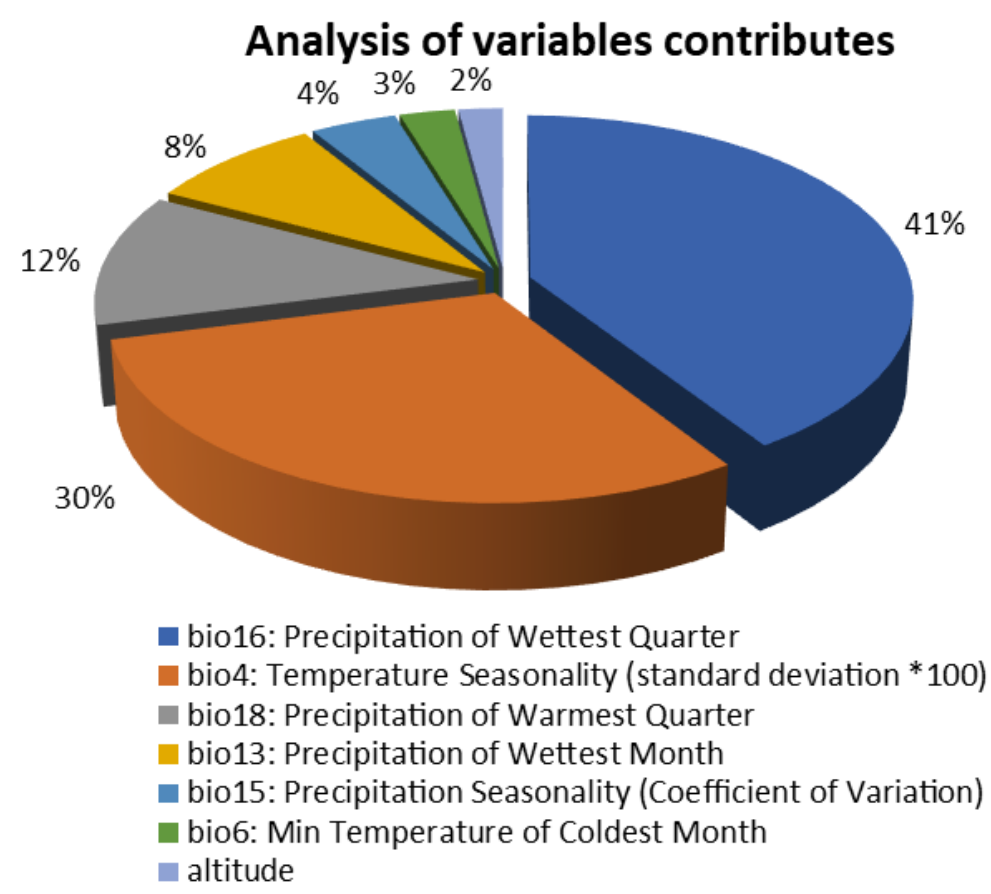

Fig.10. Analysis of variables contributes to the prediction distribution model of A. punica.

\section{DISCUSSION}

Gall-inducers usually prefer fast-growing and large plant organs, such as stems and leaves (Price, 1991). The current study showed that the stem of A. halimus is the most important part of the plant subjected to galls induction. It may be strongly attributed to enough area provided by the stem for gall induction (De Bruyn, 1994). Also, the gall-inducing insects prefer the more rewarding organs of the plant to form the gall (Whitham, 1978). Additionally, the present study suggests that the gall-inducing insects prefer the large plants more than the small ones which were evident from the positive correlation between the number of galls per plant and the plant cover. It may be attributed strongly to the availability of resources introduced by large plants, which supports the view of (Feeny, 1975). Furthermore, this agrees with the results of Daniela et al., (2008) who showed that the number of galls is positively correlated to the biomass of the host plant and its branch number and also, with the view of (Fernandes, 1992) who recorded positive relationship between gall and plant richness for the vegetation of Indonesia. Also, the results agree with the first hypotheses of (Araújo, et al., 2006) who reported that the increase of plant architecture leads to increases in species richness and abundance of gall-inducing insects. Additionally, the results agree with the view of Wright and Samways $(1996,1998)$ who showed that the richness of plant species could play a pivotal role in diversifying gall-forming species. But, the results did not agree with the view Fernandes and Price (1988) who showed that the diversity of gall-inducing insect species is independent of plant species abundance. More structurally complex plants support a greater diversity of herbivorous insects to provide more microhabitats, sites for ovipositing, and escape from natural enemies, making insects more appealing and seeming (Lázaro-González et al., 2017).

A. punica showed high sensitivity to environmental factors such as Precipitation of Wettest Quarter (BIO16), Temperature Seasonality (BIO4), Precipitation of Warmest Quarter (BIO18), Precipitation of Wettest Month (BIO13), Precipitation Seasonality (Coefficient of Variation) (BIO15), Min Temperature of Coldest Month (BIO18) and altitude. This agrees 
with (Blanche, 2000; Butterill \& Novotny, 2015; Da Costa et al., 2011) they decided that environmental factors can influence the structure of gall-inducing insect communities.

The current study found that the habitat distribution model of A. punica and its host plant $A$. halimus in Egypt can be run by using a small number of occurrence records together with environmental predictor layers for the study area through the maximum entropy modeling technique (MaxEnt). So the present study agrees with the finding of (Hernandez et al., 2006, Kamel et al., 2012) who suggested that the Maxent technique worked better for species with very small occurrence records that have relatively wide geographic distributions.

Also, the present study showed that the predicted distribution range size for A. punica is less than the total predicted distribution range size for A. halimus. The predicted distribution habitat of $A$. punica is mainly concentrated in some areas close to the Mediterranean coast. This agrees with the view of (Doğanlar, M., \& Elsayed, A. K., 2015) who reported that the distribution of $A$. punica is concentrated in Mediterranean regions. While, the predicted distribution habitat of $A$. halimus covers a wider region of the Mediterranean coast, in addition to some areas in the Nile land region, the Red Sea coast, and South Sinai. According to the present study, the MaxEnt model is an important technique for the prediction of species distribution and this agrees with the view of (Beck, 2013).

\section{Conclusion:}

The present study suggests that the gall inducers prefer the large plants more than the small ones which were evident from the positive correlation between the plant size and the number of galls per plant. Additionally, the current study showed that the predicted distribution range size for $A$. punica is less than the predicted distribution range size for $A$. halimus. The predicted distribution habitat of A. punica is mainly concentrated in the Nile's delta north coast. While, the predicted distribution habitat of $A$. halimus covers a wider region of the Mediterranean coastal land, in addition to some areas in the Nile land region, the Red Sea coast, and South Sinai.

\section{Recommendations:}

-Depend on the results and analysis of prediction; we put forward the following Suggestions:

- $\quad$ Studying more about plant galls induction in Egypt as a unique form of insect-plant interactions.

- We need to pay more attention to the suitable areas of the gall inducer A. punica and its host plant A. halimus in Egypt, which should be the important areas for protection.

- $\quad$ Collect the data from different spaced locations to make the model more accurate.

\section{REFERENCES}

Abd El-Ghani, M., Bornkamm, R., El-Sawaf, N. \& Turky, H. 2015. Heterogeneity of Soil and Vegetation in the Urban Habitats of New Industrial Cities in the Desert Landscape of Egypt. Notulae Scientia Biologicae, 7(1): 26-36.

Abdel Rahman, S.M., Abd-Ellatif, S.A., Deraz, S.F., Khalil, A.A., (2011). Antibacterial activity of some wild medicinal plants collected from western Mediterranean coast, Egypt: natural alternatives for infectious disease treatment. Afr. J. Bio- technol. 10, 733743.

Al-Sherif, E. A., Ismael, M. A., Karam, M. A. \& Elfayoumi, H. H. 2018. Weed flora of Fayoum (Egypt), one of the oldest agricultural regions in the world. Planta Daninha, 36.

Amer, W. M. \& Abdo, A. S. 2014. Infra-Specific Pollen Diversity of Atriplex halimus L. in Egyptian Flora. International Journal of Research Studies in Bio-Sciences, 2, 36-48.

Araújo, M. B., Thuiller, W. \& Pearson, R. G. J. J. O. B.(2006). Climate warming and the decline of amphibians and reptiles in Europe. journal of biogeography, 33, 1712-1728.

Bailey C, Danin A (1981): Bedouin plant utilization in Sinai and the Negev. Economic Botany, 
35: 145- 162.

Bailey R, Schönrogge K, Cook JM, Melika G, Csóka G, Thuróczy C, Stone GN (2009) Host niches and defensive extended phenotypes structure parasitoid wasp communities. PLoS Biol 7(8): e1000179.

Barredo, J. I., Strona, G., de Rigo, D., Caudullo, G., Stancanelli, G., and San-Miguel-Ayanz, J. (2015). Assessing the potential distribution of insect pests: case studies on large pine weevil (Hylobius abietis L) and horse-chestnut leaf miner (Cameraria ohridella) under present and future climate conditions in E uropean forests. EPPO Bulletin, 45(2), 273281.

Beck J., (2013). Predicting climate change effects on agriculture from ecological niche modeling: who profits, who loses?- Climate Change, 116: 177-189.

Blanche KR, (2000): Diversity of insect-induced galls along a temperature-rainfall gradient in the tropical savannah region of the Northern Territory, Australia. Austral Ecology 25:311-318.

Borges, R. M. (2015). How to be a fig wasp parasite on the fig-fig wasp mutualism. Current Opinion in Insect Science. 8: 34-40.

Boulos, L. 1999. Flora of Egypt, Vol. 1. , Cairo, Egypt, Al hadara publishing.

Bowdrey, J.P., and B.M. Spooner. (1996). Checklist of British galls and gall-causing organisms. 2. Coleoptera: preliminary list. Cecidology, 11: 36-71.

Butterill, P., \& Novotny, V. (2015). Gall-forming insects in a lowland tropi- cal rainforest: Low species diversity in an extremely specialised guild. Ecological Entomology, 40(4), 409-419.

Da Costa, F.V., de Siqueira Neves, F., de Oliveira Silva, J., \& $\quad$ Fagundes, M. (2011). Relationship between plant development, tannin concentra- tion and insects associated with Copaifera langsdorffii (Fabaceae). Arthropod-Plant Interactions, 5(1), 9-18.

Daniela P. Lara1, Lázaro A. Oliveira1, Islaine F. P. Azevedo1, Márcia F. Xavier1, Fernando A. O. Silveira Marco Antonio Alves Carneiro and G. Wilson Fernandes (2008): Relationships between host plant architecture and gall abundance and survival. Revista Brasileira de Entomologia, 52(1): 78-81.

De Bruyn, L. 1994. Life history strategies of three gall-forming flies tied to natural variation in growth of Phragmites australis. In: Price, P. W., Mattson, W. J. \& Baranchikov, Y. N. (eds.) The Ecology and Evolution of Gall-Forming Insects. U.S. Dept. Of agriculture, Forest service, North central forest experiment station.

Debski B. (1918): Liste des cecidies en Egypte jusqu'a ce jour. Mémoirs de la Société Entomologique d'Égypte, 1: 1-38.

Doğanlar, M., \& Elsayed, A. K. (2015). Parasitoids complex in summer populations of Asphondylia punica Marchal, 1897 (Diptera: Cecidomyiidae) on the Mediterranean saltbush, Atriplex halimus L.(Chenopodiaceae) in Egypt, with descriptions of new species from Eupelmidae. Munis Entomology and Zoology, 10(1), 75-85.

Dorchin, N., Mifsud, D. \& Askew, R. (2014): Saltbush-associated Asphondylia species (Diptera: Cecidomyiidae) in the Mediterranean Basin and their chalcidoid parasitoids (Hymenoptera: Chalcidoidea). Zootaxa 3869: 383-396.

Dreger-Jauffret, F., and J. D. Shorthouse. (1992). Diversity of gall-inducing insects and their galls. In Biology of Insect-Induced Galls, ed. J. D. Shorthouse and O. Rohfritsch, 833. Oxford: Oxford University Press.

Drooz AT. (1985). Insects of Eastern Forests. USDA Forest Serv., Washington, D.C. Miscellaneous Publication No. 1426. 608 p. Franklin, J. (2009) Mapping species distributions: spatial infer- ence and prediction. Cambridge University Press, Cambridge, UK.

El Hadidi, M. N., \& Hosni, H. A. (1996). Biodiversity in the flora of Egypt. In The Biodiversity 
of African Plants (pp. 785-787). Springer, Dordrecht.

El-Hadidi, M.N. (1981). The vegetation of the Nubian Desert (Nabta), Region. I. Prehistory of East Sahara. Appendix, 5, 345-351.

Elsayed AK, Skuhravá M, Karam HH, Elminshawy A, Al-Eryan MA (2015). New records and new species of gall midges (Diptera: Cecidomyiidae) developing on Chenopodiaceae in Egypt. Zootaxa, 3904:105-115

Espirito-Santo, M.M.; Fernandes, G.W. (2007): How Many Species of Gall-Inducing Insects Are There on Earth, and Where Are They. Annals of the Entomological Society of America, 100, 95-100.

Feeny, P. 1975. Biochemical coevolution between plants and their insect herbivores. Coevolution of Animals and Plants, 13, 1-8.

Fernandes, G. W. (1992). Plant family size and age effects on insular gall-forming species richness. Global Ecology and Biogeography Letters, 2:71-4.

Fernandes, G. W., \& Price, P. W. (1988). Biogeographical gradients in gall- ing species richness Tests of hypotheses. Oecologia, 76(2), 161-167.

Fourcade Y., Engler J. O., Rödder D., Secondi J., (2014). Mapping species distributions with MAXENT using a geographically biased sample of presence data: a performance assessment of methods for correcting sampling bias.- PLoS one, 9 (5): e97122.

Graham, M. De Vere, W. R. \& Gijswijt, M. J. (1998): Revision of the European species of Torymus Dalman (Hymenoptera: Torymidae). Zoologische Verhandelingen 317: 3202.

Graham, C. H., \& Hijmans, R. J. (2006) A comparison of methods for mapping species ranges and species richness. Global Ecology and biogeography, 15, 578-587.

Guisan, A., \& Thuiller, W. (2005). Predicting species distribution: offering more than simple habitat models. Ecology letters, 8(9), 993-1009.

Hegazi, E. M., Wangberg, J. K., Goodin, J. R. \& Northington, D. K. 1980. Field observations on arthropods associated with Atriplex halimus in Egypt. Journal of Arid Environments, 3, 305-308.

Hernandez, P. A., Graham, C. H., Master, L. L. \& Albert, D. L. J. E. (2006). The effect of sample size and species characteristics on performance of different species distribution modeling methods. Ecography, 29, 773-785.

Hijmans, R. J., Cameron, S. E., Parra, J. L., Jones, P. G. \& Jarvis, A. (2005). Very high resolution interpolated climate surfaces for global land areas. International Journal of Climatology, 25, 1965-1978.

Kamel, M., Semida, F. \& Abdel-Dayem, M.(2012). Galls inducing insects in Sinai Ecosystem, Egypt. Gall inducing insects and their host plants in St. Katherine Protectorate, KG Heinrich-Böcking-Straße, Germany, Lambert Academic Publishing GmbH \& Co .

Khattab, LMA, (2007). Studies on Halophytic Forages as Sheep Fodder Under Arid and Semi Arid Conditions in Egypt. Alexandria University. Ph.D. thesis.

Kim, D. E., Lee, H., Kim, M. J., \& Lee, D. H. (2015). Predicting the potential habitat, host plants, and geographical distribution of Pochazia shantungensis (Hemiptera: Ricaniidae) in Korea. Korean J. Applied Entomology, 54(3), 179-189.

Kjellberg, F., Jousselin, E., Hossaert-McKey, M., \& Rasplus, J. Y. (2005). Biology, ecology, and evolution of fig-pollinating wasps (Chalcidoidea, Agaonidae). Biology, ecology and evolution of gall-inducing arthropods, 2, 539-572.

Kumar, S., Graham, J., West, A. M., and Evangelista, P. H. (2014). Using district-level occurrences in MaxEnt for predicting the invasion potential of an exotic insect pest in India. Computers and Electronics in Agriculture, 103, 55-62.

Lázaro-González A, Hódar JA, Zamora R (2017) Do the arthropod communities on a parasitic plant and its hosts differ? Eur J Ento- mol 114:215-221 
Lv, W., Li, Z., Wu, X., Ni, W., \& Qv, W. (2011). Maximum entropy niche-based modeling (Maxent) of potential geographical distributions of Lobesia botrana (Lepidoptera: Tortricidae) in China. In International Conference on Computer and Computing Technologies in Agriculture (pp. 239-246). Springer, Berlin, Heidelberg.

Maia, V.C. (2006): Galls of Hemiptera, Lepidoptera and Thysanoptera from Central and South America. Publicações Avulsas Mus. Nac., 110, 1-24.

Mani, M. S. (1964). The ecology of plant galls. Walter Junk, The Hague, The Netherlands.

Osman, A. K. \& El-garf, I. A. (2015). Studies on the shallow wadies of the Mareotis sector of the Mediterranean coastal land of Egypt: Floristic features of Wadi Hashem. Flora Mediterranea, 25, 57-71.

Peláez, F., Collado, J., Arenal, F., Basilio, A., Cabello, A., Díez Matas, M.T., García, J.B., González Del Val, A., González, V., Gorrochategui, J., Hernández, P., Martín, I., Platas, G., Vicente, F.,(1998). Endophytic fungi from plants living on gypsum soils as a source of secondary metabolites with antimicrobial activity. Mycological Research, 102, 755-761.

Phillips, S. J., Dudík, M., \& Schapire, R. E. (2004, July). A maximum entropy approach to species distribution modeling. In Proceedings of the twenty-first international conference on Machine learning (p. 83).

Phillips, S. (2016). A brief tutorial on Maxent, versions: 3.3.1. Lessons in Conservation, 3, 108-135.

Phillips, S. J., \& Elith, J. (2013). On estimating probability of presence from use-availability or presence-background data. Ecology, 94(6), 1409-1419.

Phillips, S. J., Anderson, R. P., \& Schapire, R. E. (2006). Maximum entropy modeling of species geographic distributions. Ecological modelling, 190(3-4), 231-259.

PRICE, P. W. J. O. 1991. The plant vigor hypothesis and herbivore attack. Oikos., 244-251

Price, P. W., G. L. Waring, and G. W. Fernandes. (1986). Hypotheses on the adaptive nature of galls. Proceedings of the Entomological Society of Washington (USA). 88:361-3.

Price, P. W., Fernandes, G. W., \& Waring, G. L. (1987). Adaptive nature of insect galls. Environmental entomology, 16(1), 15-24.

Price, P.W. (2005): Adaptive radiation of gall-inducing insects. Basic Appllied Ecology, 6, 413-421.

Raman, A. (2011). Morphogenesis of insect-induced plant galls: facts and questions. Functional Ecology of Plants, 206: 517-533.

Raman, A., C. W. Schaefer, and T. M. Withers. (2005). Biology, Ecology, and Evolution of Gall-Inducing Arthropods, v. 2. New Hampshire: Science.

Rolleston, J.D., 1942. The folk-lore of venereal disease. British Journal of Venereal Diseases, $18,1-13$.

Said, O., Fulder, S., Khalil, K., Azaizeh, H., Kassis, E., Said, B., (2002). Maintaining a physiological blood glucose level with 'Glucolevel', a combination of four antidiabetes plants used in the traditional Arab herbal medicine. Evid.-Based Complement. Altern. Med. 5, 421-428.

Salem, B. 2014. Omayed Biosphere Reserve. Innovative ways for a sustainable use 471 of drylands: final report of the Sumamad Project, 60-72.

Shaltout, K. H. \& Al-Sodany, Y. M. 2008. Vegetation analysis of Burullus Wetland: a RAMSAR site in Egypt. Wetlands Ecology and Management, 16, 421-439.

Shorthouse, J.D. and Rohfritsch, O. (1992): Biology of Insect-Induced Galls, 1st ed.; Oxford University Press: Oxford, UK, pp. 1-296.

Skuhravá M. \& Skuhravý v. (1997): Gall midges (Diptera: Cecidomyiidae) of Greece. Entomologica, Bari 31: 7-68.

Skuhravá M. and Roques A. (2000): Palaearctic dipteran forest pests. Pp.: 651-692. In: papp 
1. and Darvas B. (eds.): Contributions to a Manual of Palaearctic Diptera. Volume 1. General and Applied Dipterology. Budapest: Science Herald, 978 pp.

Skuhravá M., Skuhravý V. \& Massa B. (2007): Gall midges (Diptera Cecidomyiidae) of Sicily. Naturalista Siciliano 31: 261-309.

Skuhravá, M. (1996). A new gall midge species, Etsuhoa thuriferae sp. n. (Diptera: Cecidomyiidae) from galls on Juniperus thurifera L. (Cupressaceae) in Spain. Zapateri: Revista Aragonesa de Entomología, 5: 135-146.

Täckholm V. (1974): Student's Flora of Egypt. Second Edition. Cairo: Cairo University Press, $888 \mathrm{pp}$.

Tutin, T. G.; Burges, N. A.; Chater, A. O.; Edmondson, J. R.; Heywood, V. H.; Moore, D. M.; Valentine, D. H.; Walters, S. M.; Webb, D. A., (1993). Flora Europea: Volume 1. 2nd Edition, Cambridge University Press, UK.

Uphof, J.C.Th.,(1968). Dictionaryof Economic Plants, second ed. Stechert-Hafner, New York. Walker, D. J., Lutts, S., Sánchez-García, M., \& Correal, E. (2014). Atriplex halimus L.: Its biology and uses. Journal of Arid Environments, 100, 111-121.

Whitham, T. G. J. E. 1978. Habitat selection by Pemphigus aphids in response to response limitation and competition. Ecology 59, 1164-1176.

Wright, M. G., \& Samways, M. J. (1996). Gall-insect species richness in African Fynbos and Karoo vegetation: the importance of plant species richness. Biodiversity Letters, 151155.

Wright, M.G., and M.J. Samways. (1998). Insect species richness tracking plant species richness in a diverse Bora: gall-insects in the Cape Floristic Region, South Africa. Oecologia (Berl.) 115: 427-433.

Zahran, M. A. \& Willis, A. J. 2009. The Western Desert. In: Zahran, M. A. \& Willis, A. J. (Eds.) The Vegetation of Egypt. Dordrecht: Springer Netherlands.

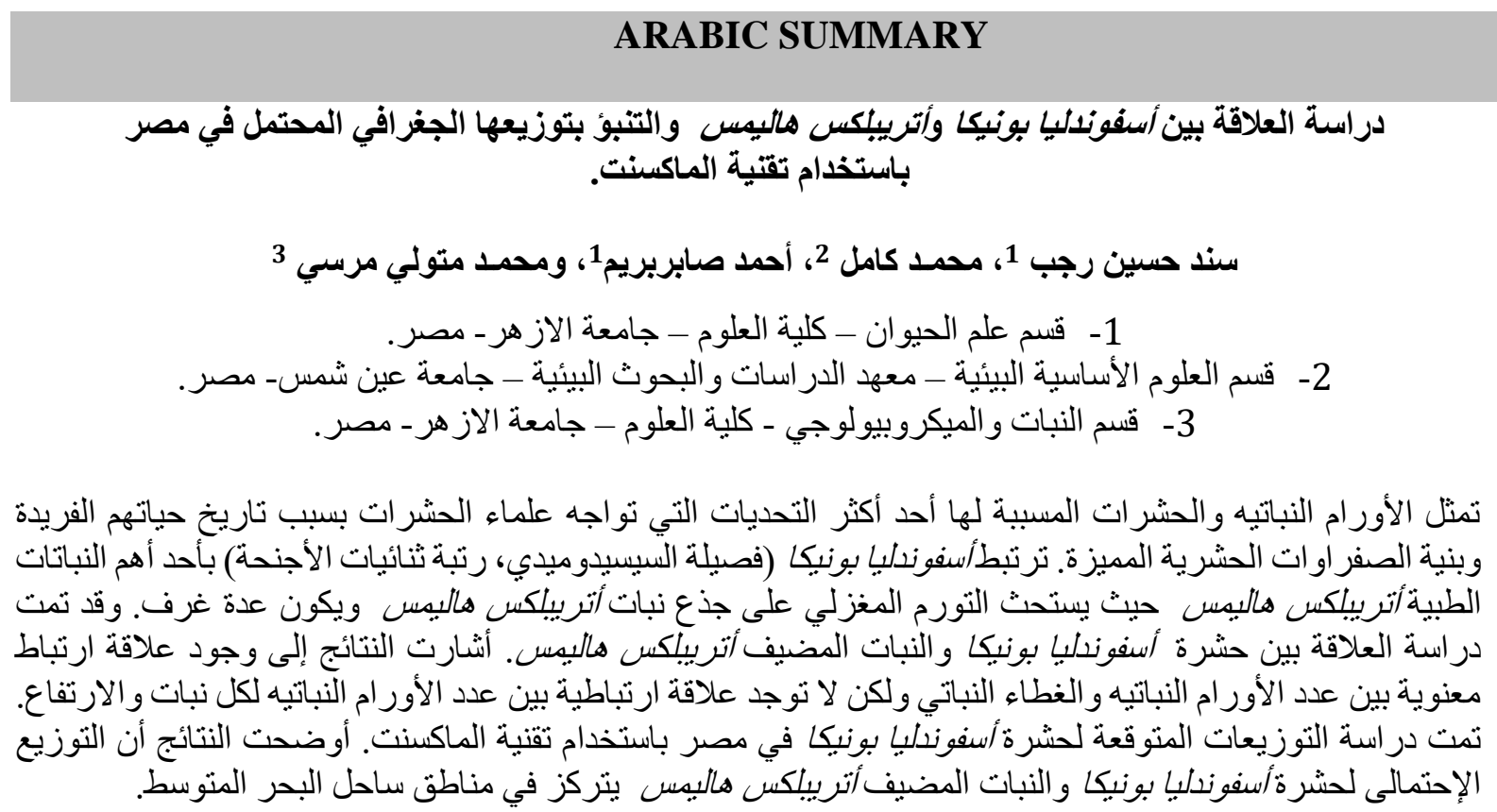

